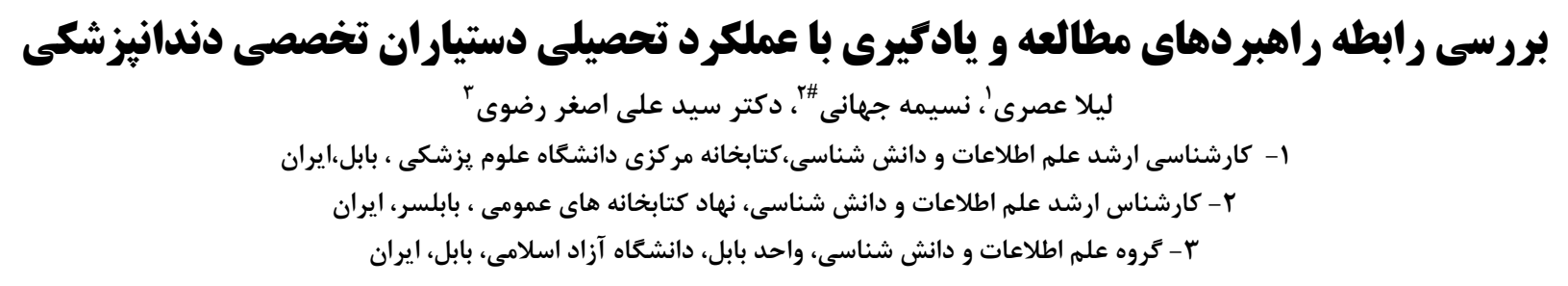

وصول مقاله: · و

\title{
Evaluation effect of Learning and study strategy on educational interventions of dental student
}

\author{
Leyla Aasri $^{1}$, Nasimeh Jahani ${ }^{2 \#}$, Seyyed Aliasghar Razavi ${ }^{r}$ \\ ${ }^{1}$ M.A. in Knowledge and Information Science, Library of Babol University of Medical Sciences, Babol, I.R. Iran \\ 2. M.A. in Knowledge and Information Science, Public Libraries Foundation, Babolsar, I.R. Iran \\ ${ }^{3}$ Ph.D. in Knowledge and Information Science, Department of Knowledge and Information Science, Islamic Azad University, Babol, I.R. Iran
}

\section{Abstract}

Received: 19 April 2018; Accepted: 5 Decemeber 2018

BACKGROUND \& AIM: Recognition of learning and study strategies is a fundamental step for educational interventions, especially in the field of medical sciences. This study aimed to determine the relationship between learning and study strategies with Academic performance of dental students of Babol University of Medical Sciences.

Material \& Methods: This descriptive cross-sectional study was carried out on 85 dental students were randomly studied. The second edition of the Learning and Study Strategies Inventory (LASSI) was completed by students after the confirmation of its validity and reliability. For ten area of motivation, attitude, time management, anxiety, concentration, study guide, self-examination, study strategies, main idea choose, time management, data were analyzed using independent t-test and variance and Pearson correlation test.

Results: Among the mean scores gained by students, the highest one obtained from ten areas $(27.65 \pm$ 5.39) was related to the main idea and the least one (14.88 \pm 4.35$)$ was related to the level of anxiety. There was no statistically significant difference between sex and study strategies. $(\mathrm{P}=0.05)$ There was positive and strong correlation between study strategies and learning with academic performance. $(\mathrm{r}=0.52)$

Conclusion: It seems, post graduate dentistry students need to be guided in some study strategies areas. Particularly, in anxiety area, which has positive and significant correlation.

Keywords: Learning strategies, study strategies, Dental students, Academic performance.

*Corresponding Author: nasimehjahani@gmail.com

J Res Dent Sci. 2019, J Res Dent Sci. 16 (1) :67-70 
سابقه و هدف : شناخت راهبردهاى مطالعه و يادَيرى، كامى اساسى براى مداخلات آموزشى بخصوص در حوزه علوم يزشكى است.

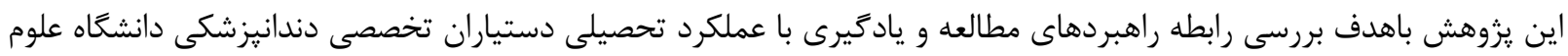
يزشكى بابل در سال عو انجام شد.

مواد و روش ها: اين مطالعه توصيفى بر روى هی نفر نفر از دستياران تخصصى دندانيزشكى كه بطور تصادفى مورد مطالعه قرار كرفتند،

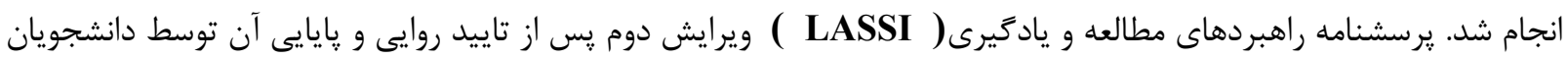

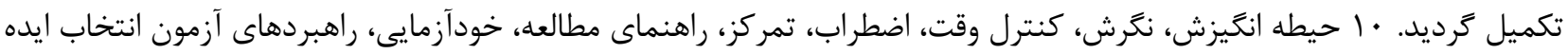

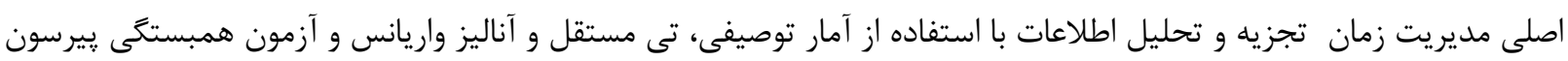
انجام كرفت.

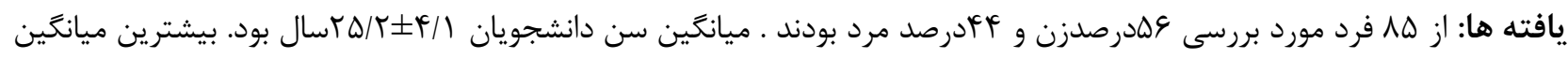

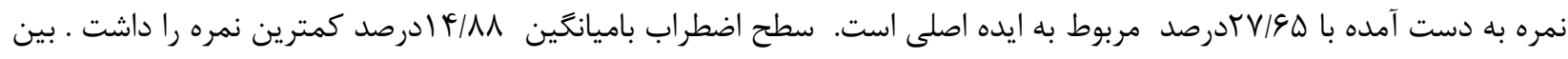

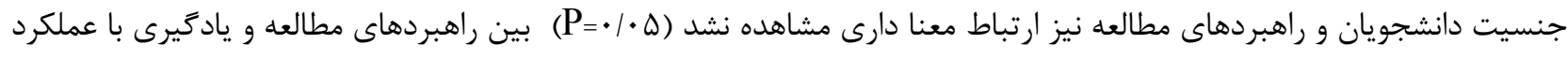

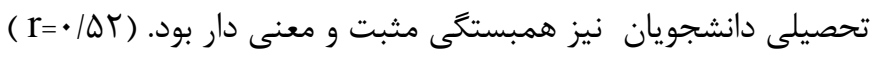

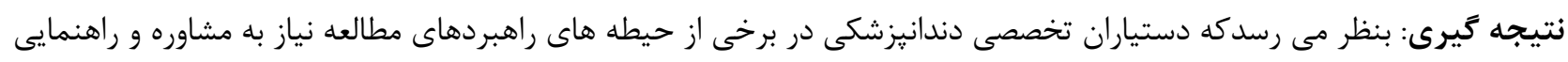

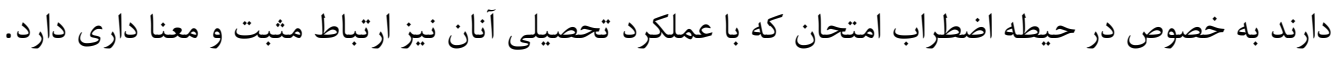

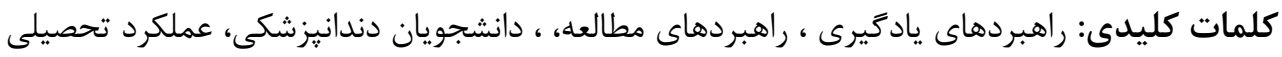

يادكيرى با هدف كسب اطلاعات بيشتر و ذخيره سازى دانش

مقدمه:

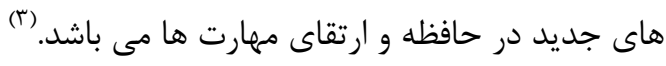
بسيارى از دانشجويان زمانى كه وارد دانشكاه مى شوند در مورد توجه به راهبردهاى مطالعه و يادكيرى و تدريس به عنوان يكى مهارت هاى ضرورى در دانشعاه كه يكى از مههم ترين آن ها رمان

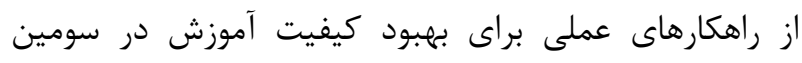

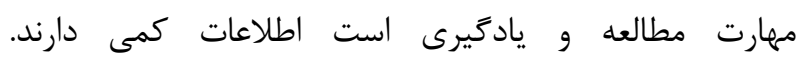
كنفرانس بين المللى آموزش يزشكى مورد تاكيد قرار كرفته

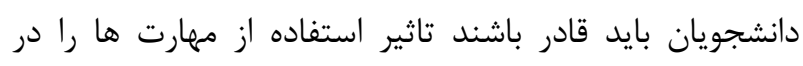

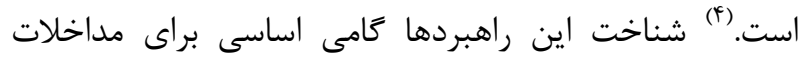

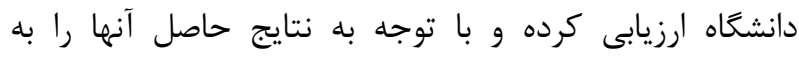
آموزشى مناسب مى باشد. (ه) آناخت

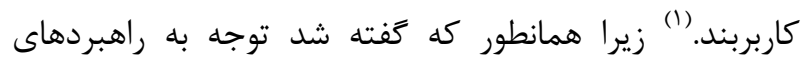

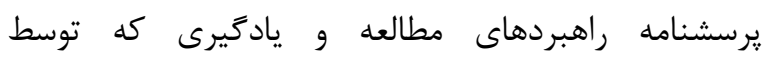

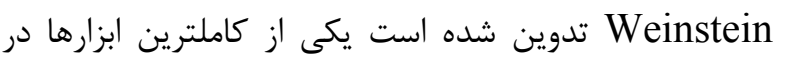

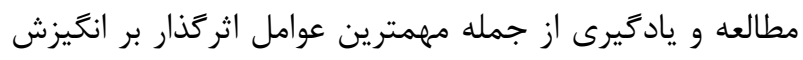
״يشرفت تحصيلى است.

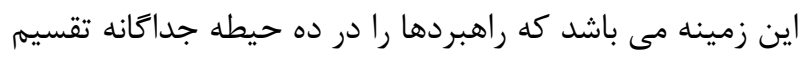

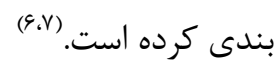
در حال حاضر اين يرسشنامه در دانشعاه هاى متعددى در جهان به منظور شناخت مشكلات تحصيلى و ارائه مشاوره به

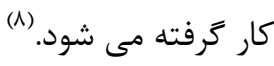
دانشجويان رشته دندانيزشكى با حجم بسيار زياد و گسترده

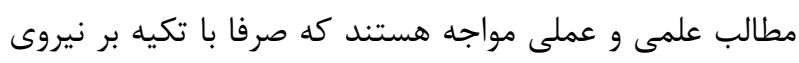
حافظه نمى توان آن ها را فرا كرفت و كاربرد راهبردهاى ماى مانى مطالعه و يادكيرى ابزار ى مناسب جهت نسان ران تسهيل فرايند

يادگيرى خواهد بود. (r) Ahmadi راهبردهاى مطالعه و يادكيرى يك فرايند سيستميك بوده كه بهد يادكيرى در دانشجويان زيشكى و دندانيزشكى دانشكاه شاهد

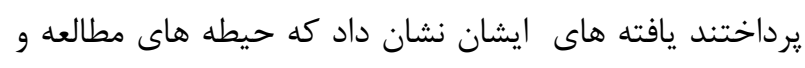

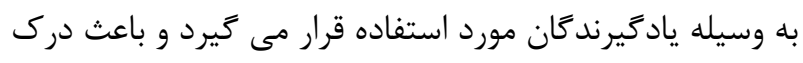
عميق و وسيع از مطالب خوانده شده مى شود و شامل مورد

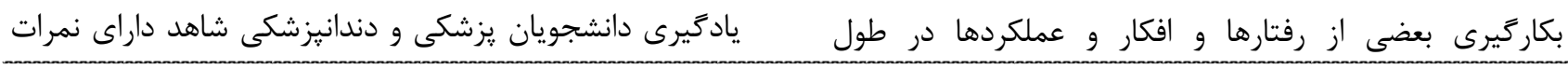


استفاده از راهبردهاى مطالعه و يادگيرى را بررسى

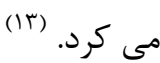
قسمت هاى مختلف يرسشنامه شامل موارد زير بود نكرش(علاقه) دانشجويان نسبت به دانشكده و تحصيل ، انخيزش( سطح يشتكار، خودتنظيمى و تمايل به سخت كوشى در انجام وظايف تحصيل)، كنترل وقت( برنامه ريزى مناسب براى استفاده از وقت براى تمام وظايف تحصيلى)، اضطراب (نترانى دانشجويان در مورد استفاده و عملكرد آنان در دانشگاه)، تمركز( توانايى دانشجويان براى توجه به وظايف تحصيلى و دروس)، يردازش اطلاعات( استفاده از بسط، پايش ميزان درك و استدلال)، راهنماى مطالعه ( استفاده از تكنيك ليك هاى حمايت كننده يا مواردى كه به يادگيرى و نيز به خاطر آوردن اطلاعات كمك مى كند)، خودآزمايى( تلاش براى مرور و آماده شدن براى كلاس و امتحان)، راهبردهاى آزمون( شناخت انواع آزمون و نحوه پاسخ دهى در آنها)، يردازش اطلاعات (ميزان مهارت بسط دادن و تفكر انتقادى را مورد بحث قرار دهيد و همان كنش و واكنش برآيندهاى هوشى است كه موجب جذب و انطباق با محيط مى شود. انتخاب ايده اصلى (توانايى فرد به منظور دسته بندى نكات اصلى و نكات كليدى و تمركز بر آنها) سوالات هر حيطه مقياس :نج درجه اى از اتا ه را شامل مى شوند) اصلا در مورد من صدق نمى كند، معمولا در مورد من صدق نمى كند، تا حدودى در مورد من صدق نمى كند، معمولا در مورد من صدق مى كند، كاملا در مورد من صدق مى كند). وين اشتاين در ويرايش r +. (זيايايى اين يرسشنامه را تعيين نمود. (If) به منظور تعيين يايايى :رسشنامه از روش ضريب آلفاى كرونباخ استفاده شده كه عدد حاصل •1 ٪ بود به منظور تعيين روايى ״رسشنامه در اختيار گֶند تن از اعضاى هيات علمى قرار زرفت و نظرات ايشان در يرسشنامه لحاظ گرديد. يرسشنامه در بين دانشجويان توزيع گرديد.و رِ از جمع آورى

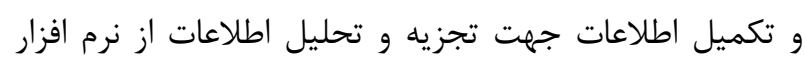

"جايين بوده است.(9) در مطالعه اى در دانشعاه ايالتى (senjose) ، مهارت هاى (se مطالعه و يادكيرى دانشجويان به وسيله LASSI سنجيده شد و هِ از ارائه يك دوره آموزش براى موفقيت تحصيلى، نسبت به قبل بهبود جشم گيرى نشان داد. (•) مطالعه اى در آفريقا نشان داد كه اضطراب و جُخونكى كاربرد راهبردهاى آزمون دانش آموزان با توانمندى هاى آنها در موفقيت در دانشعاه ارتباط دارد. (11) در يك متاآناليز با بررسى \همقاله، جنين نتيجه گرفته شد كه راهبردهاى مطالعه و يادگيرى موثرترين عامل ييشرفت تحصيلى دانشجويان محسوب مى شوند. (r) دستياران تخصصى رشته دندانيزشكى به دليل حساس بودن رشته شان نياز به راهبردهاى حمايتى دارند تا از توانايى هاى خود بهتر بهره بخيرند. هرجند كه مطالعاتى كه به بررسى راهبردهاى مطالعه و يادگيرى دانشجويان رشته يزشكى شده، اندك نيست ولى تا كنون يزوهشى كه بررسى رابطه راهبردهاى مطالعه و يادگيرى بر عملكرد تحصيلى دانشجويان رشته تخصص دندانيزشكى بيردازد انجام نشده است . . باتوجه به اهميت اين موضوع اين مطالعه با هدف بررسى رابطه راهبردهاى مطالعه و يادگيرى با عملكرد تحصيلى دستياران تخصصى دندانيزشكى دانشگاه علوم يزشكى بابل انجام شده است.

\section{مواد و روش ها - - ماد}

اين يزوهش از نوع توصيفى بود كه در خرداد ماه عهسادر دانشعاه علوم يزشكى بابل دانشكده دندانيزشكى انجام شد. جامعه يزوهش را دستياران تخصصى رشته دندانيزشكى تشكيل مى دادند. در اين يروهش هی نمونه مورد بررسى قرار كرفتند .

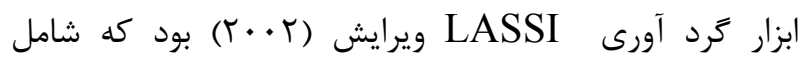
•امقياس بوده و ميزان هوشيارى و توانايى دانشجويان در 
جدول Y- ضريب همبستكى مولفه هاى راهبردهاى مطالعه و يادكيرى با عملكرد تحصيلى

\begin{tabular}{|c|c|c|c|}
\hline ضمبستكى & تعداد & متغير بِيش بين & متغير ملاك \\
\hline - $/ \Delta T$ & $\wedge \Delta$ & راهبردهاى مطالعه & تحصيلى \\
\hline
\end{tabular}

همانطور كه در جدول r مشاهده مى شود ضريب همبستگى راهبردهاى مطالعه و يادگيرى با عملكرد تحصيلى |هY| • است كه اين ضريب نشان دهنده ى همبستگى مثبت و معنى دار بين راهبردهاى مطالعه و يادَيرى با عملكرد تحصيلى است. در نمودار زير ميانه حيطه هاى ده گانه راهبردهاى مطالعه و يادگيرى دانشجويان دندانيزشكى بابل با نمونه هنجارى از دانشجويان آمريكا مقايسه گرديده است. همانگونه كه در نمودار مشاهده مى شود ميانه حيطه هاى راهبردهاى مطالعه و يادگيرى در حيطه ايده اصلى در بالاترين سطح و در حيطه اضطراب در يايين ترين حد مى باشد.
استفاده شد. در اين مطالعه مقدار PSPS در نظر گرفته شد.

\section{يافته ها:}

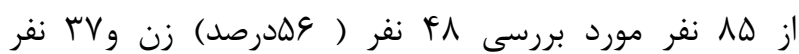

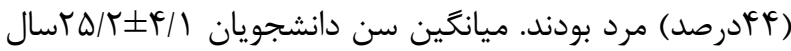

جدول ا ميزان امتياز كسب شده در هريك از حيطه هاى راهبردهاى مطالعه و يادگيرى را در دانشكده دندانيزشكى

نشان مى دهد.

جدول ا- ميزان نمرات مولفه هاى راهبردهاى مطالعه و يادگيرى

\begin{tabular}{|c|c|c|}
\hline $\mathbf{p}$ & ميانغين و انحراف معيار & حيطه ها \\
\hline$\cdot \mid \Delta V$ & $r / 99 \pm T V / T)$ & راهبردهاى آزمون \\
\hline$\cdot|r|$ & $F / \Gamma) \pm r \varepsilon / 9 \Delta$ & يردازش اطلاعات \\
\hline$\cdot 1 \mathrm{~A} \Lambda$ & $\Delta / \Delta १ \pm r V / \varphi \Delta$ & انتخاب ايده اصلى \\
\hline$\cdot / \& V$ & $F / Y \wedge \pm r \varepsilon / \Delta F$ & انخيزش \\
\hline$\cdot / \pi 1$ & $\mathcal{F} / \Lambda \Lambda \pm r \Delta / \mathcal{F}$ & 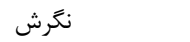 \\
\hline$\cdot 110$ & $F / r \Delta \pm I f / \Lambda \Lambda$ & اضطراب \\
\hline$\cdot / T \Lambda$ & $\Delta / r q \pm r V / \Delta F$ & تمركز \\
\hline$\cdot \pi \Delta$ & $F / D F \pm Y F / G \Lambda$ & راهنماى مطالعه \\
\hline אז/. & $\Delta / / \varepsilon \pm Y r / \Lambda)$ & خودآزمايى \\
\hline$\cdot / r \Delta$ & $r / q) \pm r r / q)$ & مديريت زمان \\
\hline
\end{tabular}

بيش ترين ميانگين و انحراف معيار در كل جامعه مورد بررسى

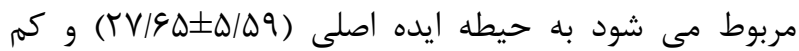
ترين ميانگين مربوط به سطح اضطراب است (ه/ در بررسى تفاوت ميانگين نمرات بين دختران و پِران تفاوت

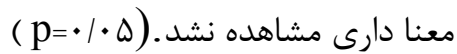


نمودار ا : ميانه حيطه هاى ده كانه راهبر دهاى مطالعه و يادكيرى دانشجويان دندانيزشكى بابل با نمونه هنجارى از دانشجويان آمريكا

\begin{tabular}{|c|c|c|c|c|c|c|c|c|c|c|}
\hline نكرش & انگَيزش & كنترل & اضطراب & تمركز & اطردازش إعات & انتخاب اصلى & راهنماى & خود آزمايى & راهبردهاى & صدى \\
\hline f. & f. & f. & f. & f. & f. & f. & rı & f. & $r$. & 99 \\
\hline rq & rq & $r v$ & $r v$ & $r v$ & $r \Lambda$ & $r \wedge$ & r & r & $r v$ & 90 \\
\hline rA & $r \Lambda$ & ra & ro & ra & ro & $r v$ & m & $r r$ & ra & 9. \\
\hline$r v$ & $r v$ & $r F$ & $r F$ & $r f$ & $r F$ & $r \Delta$ & $r$. & $r$. & $r F$ & $\wedge \Delta$ \\
\hline ro & rq & rr & rr & r & rr & $r F$ & $r q$ & rq & rr & $\Lambda$. \\
\hline- & - & r & r & rr & $r$ & rr & $r \wedge$ & - & - & $V \Delta$ \\
\hline rq & ro & - & $r$. & r & $r$. & rr & rV & rA & rr & $v$. \\
\hline- & rF & $r$. & rq & $r$. & - & ו & TE & TV & -- & 90 \\
\hline rd & rr & $r q$ & $r \wedge$ & $r q$ & rq & $r$. & - & - & ו & q. \\
\hline- & - & TV & TV & - & $r \wedge$ & rq & rd & rq & - & $\Delta \Delta$ \\
\hline$r F$ & rr & - & re & $r \wedge$ & TV & - & - & rd & $r$. & $\Delta$. \\
\hline r & rl & & & rV & & & TF & - & rq & $F D$ \\
\hline ra & Tr & ra & rd & $r \Delta$ & TD & TV & $r r$ & TF & - & f. \\
\hline TF & TF & TF & TF & TF & TF & rq & - & & $r \wedge$ & ro \\
\hline r & r & & r & $r H$ & rr & rd & rT & - & rV & $r$. \\
\hline rr & rT & 7 & rT & $r$ & Tr & $r F$ & $r$ & $r$ & Tq & $r \Delta$ \\
\hline rI & $r$ & $r^{\prime}$ & rI & $x$ & rI & r & $r$. & $r$. & $r \Delta$ & $r$. \\
\hline 11 & 11 & 11 & 4 & $\Lambda$ & 11 & Tr & 19 & 19 & TF & 10 \\
\hline ir & $r$ & Ir & 14 & ir & ir & rI & 11 & 11 & $r r$ & 1. \\
\hline$r \Delta$ & ro & $r \Delta$ & ra & TS & rd & 11 & 18 & 19 & 19 & $\cdot \Delta$ \\
\hline TF & YF & TF & TF & $T_{F}$ & TF & $\pi$ & $\pi$ & $\pi$ & If & +1 \\
\hline
\end{tabular}

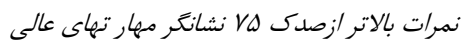

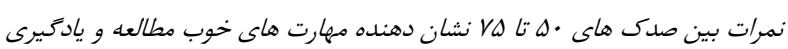

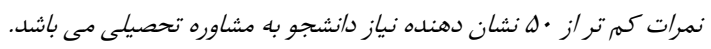


مولفه كنترل اضطراب يرسشنامه راهبردهاى مطالعه و يادكيرى بحث: كسب نمودند. و ارتباط آمرى تمام مولفه هاى راهبردهاى رئي مطالعه و يادَيرى با اضطراب امتحان در سطح معنا دار بود. كه

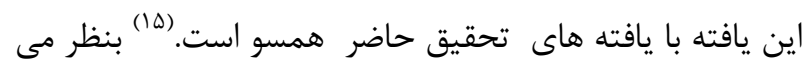
رسد سختى دروس و جِكَنكَى طراحى سوالات امتحان توسط اساتيد و عملى بودن بسيارى از دروس امتحانى و ضعيت دروسيت

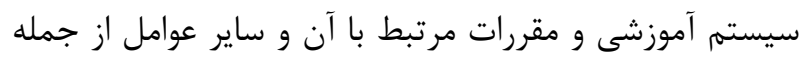

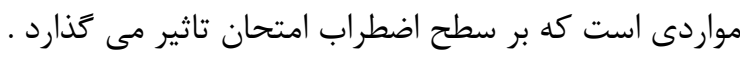

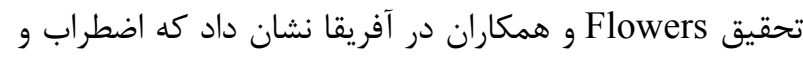

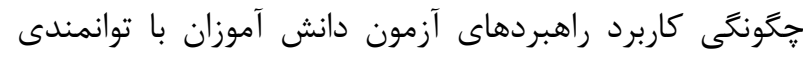

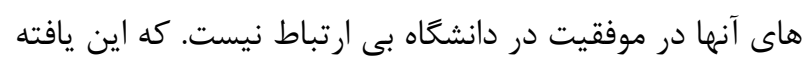
با تحقيق حاضر مشابهت دارد در تحقيق حاضر نيز دردين راهبردهاى مطالعه و يادَيرى و عملكرد تحصيلى دانشجويان ارتباط مثبت و معنادار بود. (11)

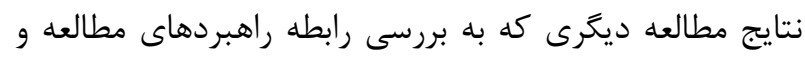

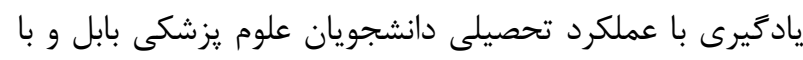
استفاده از يرسشنامه راهبردهاى مطالعه و يادخيرى استاندارد Lasi

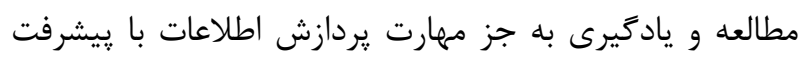

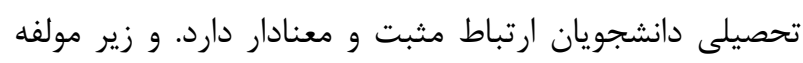

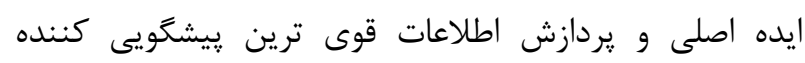

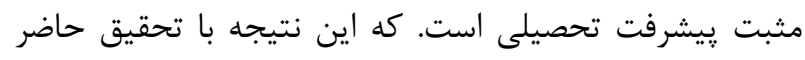

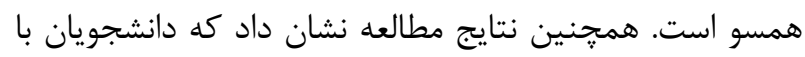
ييشرفت تحصيلى بالاتر نسبت به دانشجويان با پيشرفت تحصيلى پايين تر، در تمامى مولفه هاى راهبردهاى يادگيرى

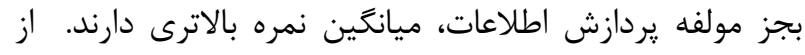
طرفى نتايج اين مطالعه نشان داد كه ميانخين تمامى زير مولفه هاى اشتياق، مهارت و خود نظم دهى در دختران به طور معنى دارى از يسران بيشتر بود كه اين نتيجه با نتايج مطالعه حاضر لهر

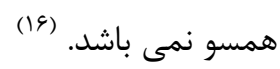
نتايج نشان داد كه بيشترين ميانگين مربوط به ايده اصلى و

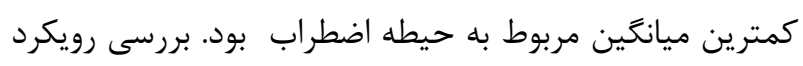

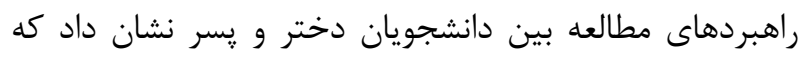
بين دانشجويان دختر و يسر تفاوت معنى دار و وجود ندارد.

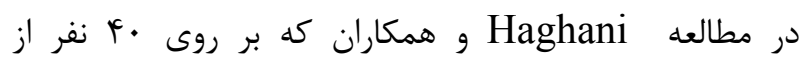
دانشجويان يزشكى و.9 نفر از دانشجويان دندانيزشكى انجام

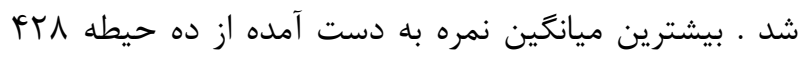
مربوط به حيطه ى انتخاب ايده اصلى بوده است كه بين اين بين

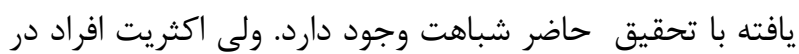
اين مطالعه برخلاف مطالعه ما، داراى نمرات پإيين بودند. بايد خاطر نشان كرد كه در مطالعه Haghani و مو همكاران تفاوت ميانگين نمرات بين دختران و يسران تفاوت آمارى دهر معنادار بين راهبردهاى آزمون انتخاب ايده اصلى آنان مشاهده كرديد. از طرفى اين مطالعه بر روى تمامى دانشجويان علوم

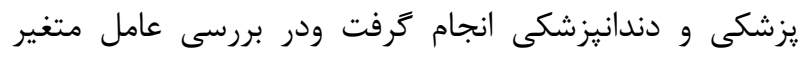

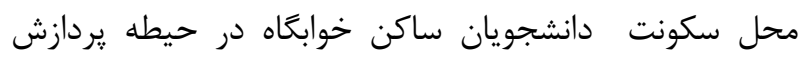
اطلاعات از ميانكين كمترى نسبت به دانشجويان ساكن در

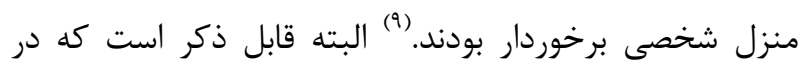
يزوهش حاضر متغير محل سكونت مورد مطالعه قرار نكرفت.

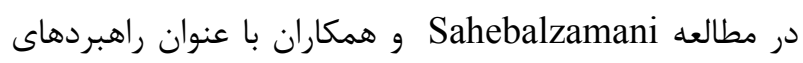

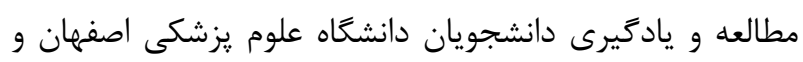

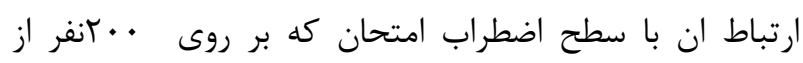

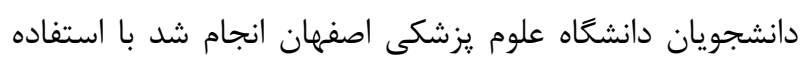

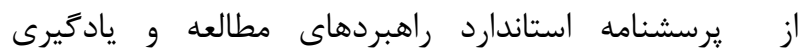
و اضطراب امتحان Weinstein ابزاركردآورى داده ها بود نتايج مشابهى با مطالعه ما به دست إن إنه

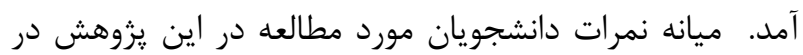
حيطه انتخاب ايده اصلى در سطح بالاترى نسبت به نمونه

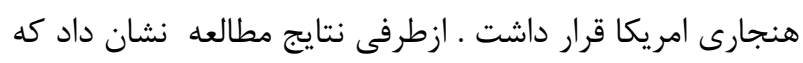
دانشجويان دانشعاه علوم يزشكى اصفهان كمترين ميانگَين را از 
نتايج مطالعه حاضر همسو است. در نهايت پِيشنهاد مى شود به

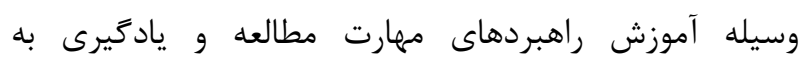

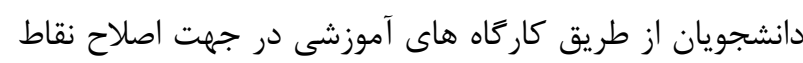
ضعف دانشجويان كام برداشت. و برنامه ريزان آموزشى شرايطى إنى را فراهم نمايند تا با ايجاد بهترين محيط هاى يادكيرى زمينه

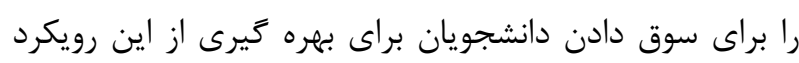

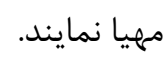

\section{نتيجه كيرى}

بنظر مى رسدكه دانشجويان دندانيزشكى در برخى از حيطه

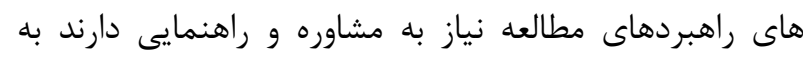
خصوص در حيطه اضطراب امتحان كه با عملكرد تحصيلى آنان نيز ارتباط مثبت و معنا دارى دارد.
در مطالعه اى كه در نروز توسطBraten و همكاران صورت كرفت نشان داد كه دختران بيشتر از استراتزى هاى مطالعه و

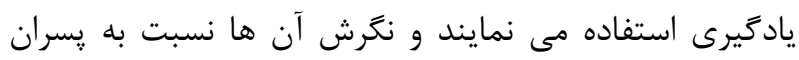

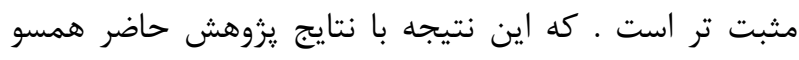

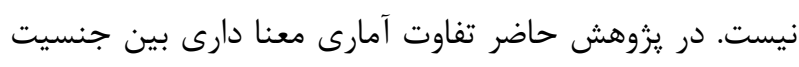

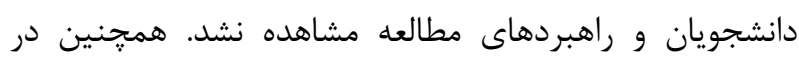
مطالعه نرور، دانشجويان سال هاى بالاتر نسبت به دانشجويان سال هاى اول از راهبردهاى مطالعه بيشتر استفاده

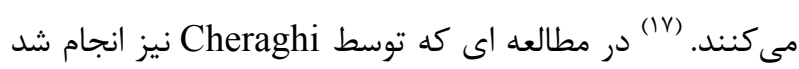
نتايج نشان داد كه در مولفه هاى نكرش، تمركز و انخيزش،

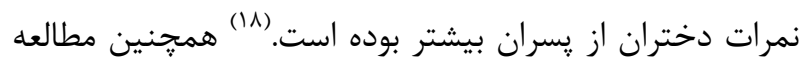

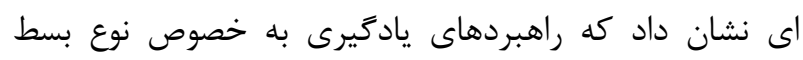

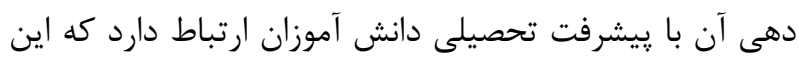
يافته با يافته هاى تحقيق حاضر همسو است در تحقيق حاضر دان

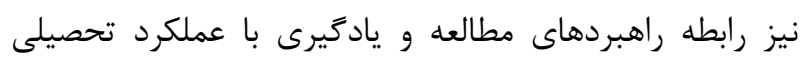

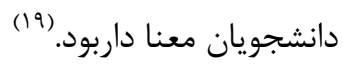
در مطالعه ديخر كه توسط Khorsandi انجام گرفت راهبردهان مدردي

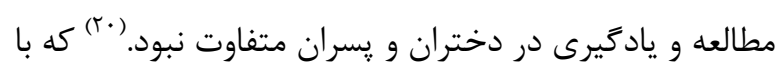




\section{References:}

1.RachalKc.Daiglesh, RachalWs. Learning Problems Reported y college Studens: Are They Using LesrningStrategies?J instructional psychology.2007;34(4): 191-199.

2.TafazolM,KhadivadivzadehT. [Midwifery students Learning styles].Aasrar 2002; 9(2):10-15.

3.CorkettGK,ParrilaR, iteinSF.Learning and study strategies of university student who report a significant history of reading difficult. Development Disabilities bulletion 2006; 34(182):57-79

4. The world federation for medical education. World summit on medical education.The changing medical.profession. 1993.

5.SaifAA,Saif AA.[Ravanshenasiparvareshi, ravanshenasiyadgirivaamoozesh]. $2^{\text {th }}$ ed.Tehrsn: Agah.2004.

6. Weinstein CE-LASSI\& H publishing Co.1987.

7. Weinstein CE,Palmer Shultz. Learning and study strategies inventory. Forida: H\& H publishing Co.1987.

8. Weinstein CE, HusmanJ, Dierking DR.Self regulation interventions with a focusonLearning strategies. In: BBookaertsM,PintrichPR, ZeidnerM. Handbook of self regulation. NewYork:AcademicPress.2000.

9.Soleiman A, Zahra Jouhariz, Haghani F. [Medical and Dental Students' Learning and Study Strategies inShahed University].Iranian Journal of Medical Education 2014: 13(10)

10. Ince EJ, PriestR.Changes in LASSI Scores among reading and study skills students at the Vnited states Military Academy 1998.Research and teaching in Developmental Educaltion 1998;14(2):19-26.

11.FlowersLa,BridgesBk,MooreJL.Concurrentvalidity of the Learning and study strategies Inventory(LassI);astuy of African American Precollege students.J Black Stud.2012;43(2):146-60.

12. Donker As, de Boer H, Kostons D, Dignath van EwijK CC, van der Werfa MPC. Effectiveness of learning strategy instruction on academic performance: A meta- analysis. Edu Res Rev.2014;11:1-26

13. Kirby JR, SilvestriR, Alling ham BH, ParrilaR, Lafave CB. Learning strategies and study approaches of Postsecondary student with Dyslexia..JLearning Disabilities.2008;41(1):85-96

14.weinsteince, PALMER Dr.Learning and study strategeies Inventory(LASSI).2Ed.clearwater,FL:H\&Hpublishing;2002.

15. Saheb Alzamani1M, ZirakA.[Students' Learning and Study Strategies in Isfahan University of Medical Sciences and their relationship with Test Anxiet]. Iranian Journal of Medical Education2011:11(1).

16. BabaeiShirvani z, Faramarzi M, Naderi H, Fakhri S. Relationship between Studying and Learning Strategies and Academic Performances in Medical Sciences Students. Education Strategies in Medical sciences. 2015:8(3):165170.
17.Braten I, Olaussen BS. The learning and study strategies of Norwegian first-year college students. Learning and individual differences. 1998; 10(4): 309-327

18. Cheraghi F, Shamsaei F, Shaikholsalmi F, Hasantehrani T. Relationship between self-efficacy and learning and study strategies in nursing and midwifery students of Hamedan university of medical sciences. Iran J Med Educ. 2013;13(4):331-40.

19. Areepattamannil S. Are learning strategies linked to academic performance among adolescents in two states in india? A tobit regression analysis. J Gen Psychol. 2014:141(4):408-24.

20.Khorsandi F, Kamkar M, Malekpour M. Relation of five basic factors of personality and self-regulated of learning approach among Isfahan girls and boys high school students in academic year 1386-87. New Educ Approach. 2010;5(2):41-64. 